\title{
Short-term inhibitory effects of $\mathrm{TiO}_{2}$ NPs on Anammox process
}

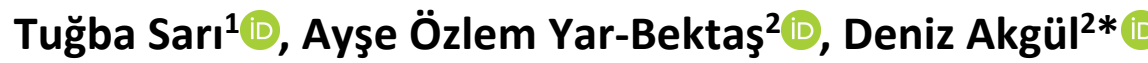

${ }^{1}$ Department of Bioengineering, Marmara University, 34722 Göztepe, Istanbul, Turkey.
${ }^{2}$ Department of Environmental Engineering, Marmara University, 34722 Göztepe, Istanbul, Turkey.

\section{Article History}

Received 16 May 2020

Accepted 12 June 2020

First Online 15 June 2020

\section{* Corresponding Author}

Tel.: +905363086006

E-mail:

deniz.tufan@marmara.edu.tr

\section{Keywords}

Anammox bacteria

Nanoparticles

Acute inhibition

Nanoparticle toxicity

\begin{abstract}
Anammox process has brought about cost-effective, eco-friendly, and innovative technologies to wastewater treatment by reducing the operational cost of treatment plants and decreasing greenhouse gas emissions. Titanium dioxide $\left(\mathrm{TiO}_{2}\right)$, as one of the most prevalent nanoparticles (NPs) in the world, is being used in various consumer products and applications. In recent years, studies have focused on potential toxicological impacts of NPs on biological processes due to their endless production and consumption. In this context, the first time in the literature, $24 \mathrm{~h}$ acute $\mathrm{TiO}_{2} \mathrm{NPs}$ exposure on Anammox process was investigated. Deterioration on anammox activity gradually increased with increasing applied $\mathrm{TiO}_{2} \mathrm{NPs}$ concentration. At $300 \mathrm{mg} / \mathrm{L}$ exposure dose, nitrogen removal rate dramatically decreased to $37.09 \pm 0.24 \mathrm{mgN}$ / gVSS.d and a severe inhibition $(80.57 \% \pm 1.17 \%)$ was observed. Among the several curve fit models, non-linear second order polynomial (quadratic) model was the best fit one with $\mathrm{IC}_{50}$ of $154 \mathrm{mg} / \mathrm{L}$. Scanning electron microscope (SEM) images demonstrated the tendency of $\mathrm{TiO}_{2} \mathrm{NPs}$ to aggregate and attach to the surface of the bacteria. Extracellular polymeric substance (EPS) response of anammox bacteria was also investigated and it was found that, the total EPS content gradually decreased by increasing $\mathrm{TiO}_{2} \mathrm{NPs}$ concentration.
\end{abstract}

\section{Introduction}

Nitrogen participates in the structure of many important biomolecules such as ATP, chlorophyll, nucleic acids and vitamins as the most abundant element in the universe. However, nitrogen in dinitrogen gas $\left(\mathrm{N}_{2}\right)$ form is inaccessible to most of the living organisms, especially primary producers. Therefore, the nitrogen cycle can be thought as one of the most essential biological processes that ensure the continuity of life (Stein \& Klotz, 2016). Nitrification and denitrification are two essential processes involved in the nitrogen cycle. Inspired by the uniqueness of the nature, they have been immensely applied to wastewater treatment systems in order to remove nitrogen and prevent eutrophication. In these processes, ammonia $\left(\mathrm{NH}_{3}\right)$ is firstly transformed to nitrite $\left(\mathrm{NO}_{2}{ }^{-}\right)$and subsequently to nitrate $\left(\mathrm{NO}_{3}{ }^{-}\right)$by nitrifiers. Thereafter, $\mathrm{NO}_{3}{ }^{-}$is reduced into various nitrogen forms including $\mathrm{NO}_{2}^{-}$, nitric oxide (NO), nitrous oxide $\left(\mathrm{N}_{2} \mathrm{O}\right)$ and $\mathrm{N}_{2}$ by denitrifiers (Heil et al., 2016; Robertson \& Groffman, 2015).

Towards the end of the 20th century, global nitrogen cycle has been updated along with the discovery of anaerobic ammonium oxidation (anammox) bacteria by Mulder et al. (1995). Anammox reaction refers to the direct conversion of ammonium to $\mathrm{N}_{2}$ via nitrite, in the absence of oxygen. Furthermore, Anammox process has brought about cost-effective, eco-friendly and innovative technologies to environmental fields e.g. industrial and domestic wastewater treatment systems (Peeters \& van Niftrik, 2019). Remarkable reduction of operational cost is the main advantage of this promising technology over conventional nitrification/denitrification. In this process, there is no need for external carbon source, sludge production is $80 \%$ less, and aeration cost decrease by $60 \%$ (Cao et al., 2017).

Despite all advantages of the Anammox process and its application in over 200 wastewater treatment 
facilities worldwide, anammox bacteria have slow growth rate and low cell yield (Zhang et al., 2016) which make the start-up and operation challenging. They are also susceptible to both inhibitory compounds such as antibiotics, heavy metals, nanoparticles (NPs) (Jin et al., 2012), and environmental factors such as $\mathrm{pH}$, temperature and dissolved oxygen. All the aforementioned factors restrict the application and industrialization of anammox-based processes.

The manipulation of physicochemical properties of NPs (1-100 nm) such as size, shape, charge and coating promotes the widespread implementation of them into various industries including medical, food, military and cosmetic sectors (Bhushan, 2017; Kaphle et al., 2018). The global nanomaterials market was valued USD 7.3 billion in 2016 and is expected to the reach USD 16.8 billion by 2022 (Liu et al., 2019). Titanium dioxide $\left(\mathrm{TiO}_{2}\right)$ as one of the most prevalent NPs in the world, is being used in many cosmetic products including sunscreens, beauty products, toothpastes. Dietary supplements, candies, sweets, prosthetic implants, food colorants, paints, plastics, pigment production, anti-fogging car mirrors, ink, coating, photocatalysts are other examples of $\mathrm{TiO}_{2}$ NPs applications (Chen \& Chen, 2017; Mohamed, 2018).

NPs may be released into the ecosystems at every stage of their life cycles. Not only the fate of them in the environment, but also their toxicity levels are determined by their physicochemical properties which undergo some changes in different environment matrices (Liu et al., 2019; Senapati \& Kumar, 2018). A significant amount of NPs has been detected in wastewaters and solid waste landfill sites (Keller \& Lazareva, 2014; Musee et al., 2011). Therefore, their potential environmental toxicity has become a great concern because of the continuous increment in manufacturing and utilization of NPs (Chen \& Chen, 2017). Besides, considering their relatively small size, more freely movement and larger surface area, they can be more toxic than larger particles in the bulk (Gupta \& Xie, 2018). This is because entrance of them into the cells is much easier and they can cause cell damage (Liu et al., 2011).
Previously, several studies have been published to reveal the potential impacts of NPs on biological wastewater treatment systems including biological nitrogen and phosphorus removal (Wu et al., 2018; Zheng et al., 2011), anaerobic digestion (Lombi et al., 2012; Mu \& Chen, 2011; Zhang et al., 2019) and anammox process (Li et al., 2018; Xu et al., 2019; Z. Z. Zhang et al., 2018a). Currently, there are only 3 studies focusing on the potential impacts of $\mathrm{TiO}_{2} \mathrm{NPs}$ on anammox process. However, 2 of them highlight the chronic (long term) effects of $\mathrm{TiO}_{2} \mathrm{NPs}$ (X. J. Zhang et al., 2018b; Z. Z. Zhang et al., 2018b) while the last one implies the short-term effects of $\mathrm{TiO}_{2} \mathrm{NPs}$ on anammox with the acute exposure tests of $8 \mathrm{~h}$ (X. J. Zhang et al., 2018a). A recent study stated that, $12 \mathrm{~h}$ exposure of inhibitory compounds is not sufficient to observe the defense mechanisms of anammox bacteria due to their slow growth rate (Song et al., 2018). Therefore, although the studies published in the current literature have enhanced our knowledge about the potential impacts of $\mathrm{TiO}_{2} \mathrm{NPs}$ on anammox process, short-term inhibitory effects of $\mathrm{TiO}_{2}$ NPs on this process has not clearly been demonstrated yet. In the light of them, this study aimed to investigate the acute impacts of $\mathrm{TiO}_{2} \mathrm{NPs}$ on anammox process. In order to achieve this, seven different $\mathrm{TiO}_{2}$ NPs doses $(1,10,50,75,100,200,300$ $\mathrm{mg} / \mathrm{L}$ ) applied to laboratory-scale anammox bioreactor for $24 \mathrm{~h}$. $\mathrm{IC}_{50}$ value of $\mathrm{TiO}_{2} \mathrm{NPs}$ was studied with several inhibition models. In addition, extracellular polymeric substance (EPS) response of enriched anammox culture and changes in surface morphology of anammox bacteria were revealed by SEM analysis.

\section{Materials and Methods}

Anammox seeding sludge and experimental setup

A $2 \mathrm{~L}$ lab-scale anammox bioreactor was established in order to enrich the anammox bacteria and use for acute exposure tests. Experimental setup is illustrated in Figure 1. Seeding sludge was obtained from an up-flow anammox bioreactor which have been being operated for more than 10 years in our laboratory. The reactor was operated in sequencing batch reactor (SBR)

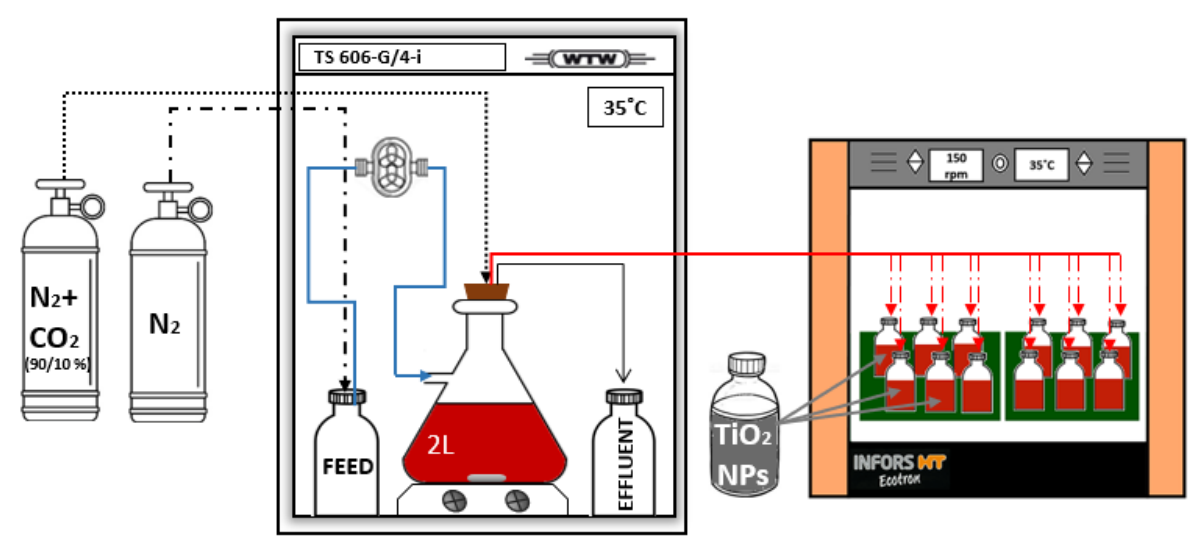

Figure 1. Experimental setup of the study. 
mode for $24 \mathrm{~h}$ cycle with fill, reaction, settling and effluent withdrawal time of $20 \mathrm{~min}, 22.67 \mathrm{~h}, 40 \mathrm{~min}$ and $20 \mathrm{~min}$, respectively. Synthetic wastewater to feed the Anammox bioreactor was prepared as previously described by Yapsakli et al. (2017), containing 1:1.15 ratio of $\mathrm{NH}_{4}{ }^{+}-\mathrm{N}$ and $\mathrm{NO}_{2}{ }^{-}-\mathrm{N}, 0.073 \mathrm{~g} / \mathrm{L} \mathrm{CaCl}_{2}, 0.174 \mathrm{~g} / \mathrm{L}$ $\mathrm{K}_{2} \mathrm{HPO}_{4}, 0.102 \mathrm{~g} / \mathrm{L} \mathrm{MgCl}_{2}, 1 \mathrm{ml}$ of trace element solution 1 (10 g/L Na 2 EDTA $2 \mathrm{H}_{2} \mathrm{O}$ and $\left.5 \mathrm{~g} / \mathrm{L} \mathrm{FeSO}_{4}\right)$ and trace element solution $2\left(10 \mathrm{~g} / \mathrm{L} \mathrm{Na}{ }_{2} E D T A \cdot 2 \mathrm{H}_{2} \mathrm{O}, 0.43 \mathrm{~g} / \mathrm{L}\right.$ $\mathrm{ZnSO}_{4} \cdot 7 \mathrm{H}_{2} \mathrm{O}, 0.24 \mathrm{~g} / \mathrm{L} \mathrm{CoCl}_{2} \cdot 6 \mathrm{H}_{2} \mathrm{O}, 0.99 \mathrm{~g} / \mathrm{L} \mathrm{MnCl}_{2} \cdot 4 \mathrm{H}_{2} \mathrm{O}$, $0.25 \mathrm{~g} / \mathrm{L} \mathrm{CuSO}_{4} \cdot 5 \mathrm{H}_{2} \mathrm{O}, 0.19 \mathrm{~g} / \mathrm{L} \mathrm{NiCl}_{2} \cdot 6 \mathrm{H}_{2} \mathrm{O}$, and $0.014 \mathrm{~g} / \mathrm{L}$ $\mathrm{H}_{3} \mathrm{BO}_{4}$ ). Besides, in order to prevent anaerobic environment that may lead to septic conditions, $50 \mathrm{mg} / \mathrm{L}$ $\mathrm{NaNO}_{3}$ was introduced to the synthetic feed solution. $1.04 \mathrm{~g} / \mathrm{L} \mathrm{NaHCO}_{3}$ was also supplied to the synthetic feed to prevent $\mathrm{pH}$ changes during the operation. Prior to feeding, in order to get rid of oxygen suppression risk, dissolved oxygen was stripped from the synthetic wastewater solution with $\mathrm{N}_{2}$ gas.

A TS 606-G/4-i incubator (WTW, Germany) was used to maintain the mesophilic environment ( $35 \pm 0.5$ $\left.{ }^{\circ} \mathrm{C}\right)$ to the anammox bioreactor. Hydraulic retention time (HRT) and $\mathrm{pH}$ were set to be 2 days and $7.5 \pm 0.3$, respectively. $\mathrm{N}_{2} / \mathrm{CO}_{2}(90 / 10 \%)$ gas mixture was also supplied to the reactor for inorganic carbon requirement.

\section{Preparation of $\mathrm{TiO}_{2}$ stock solution}

The stock solution containing NPs, was prepared according to $\mathrm{Mu}$ et al. (2012). Commercially produced $\mathrm{TiO}_{2} \mathrm{NPs}(<25 \mathrm{~nm}$ ) (Sigma Aldrich, USA) was added to the $0.1 \mathrm{mM}$ sodium dodecylbenzene sulfonate (SDBS) to prepare $1 \mathrm{~g} / \mathrm{L} \mathrm{TiO}_{2} \mathrm{NPs}$ stock solution in order to provide stability of NPs and prevent agglomeration of them. Thereafter, stock solution was sonicated for $1 \mathrm{~h}$ at $25^{\circ} \mathrm{C}$, $40 \mathrm{kHz}, 250 \mathrm{~W}$ by Sonopuls Ultrasonic Homogenizer (Bandelin, Germany).

\section{Acute exposure tests}

In order to conduct batch exposure tests, synthetic wastewater solution, NPs and enriched anammox culture were transferred into amber serum flasks having an effective volume of $50 \mathrm{~mL}$. Synthetic wastewater composition (100 mg/L NH${ }^{+}-\mathrm{N}$ and $115 \mathrm{mg} / \mathrm{L} \mathrm{NO}_{2}^{-}-\mathrm{N}$ ) was the same with that of parent reactor and $\mathrm{pH}$ was adjusted to $7.5 \pm 0.2$. Each serum flask contained $1.5 \mathrm{~g} / \mathrm{L}$ $\pm 0.5 \mathrm{~g} / \mathrm{L}$ volatile suspended solids (VSS). Prior to starting experiment, serum flasks were purged by $\mathrm{N}_{2}$ gas for 3 min to remove dissolved oxygen. Subsequently, all serum flasks were sealed with rubber stoppers and aluminum crimps. $24 \mathrm{~h}$ incubation was performed in Ecotron incubation shaker (INFORS HT, Sweden) at $35^{\circ} \mathrm{C}$ and $150 \mathrm{rpm}$. In order to determine the specific nitrogen removal rates, $0.5 \mathrm{~mL}$ well-mixed liquid samples were taken from the flasks every 3 hours. Each exposure experiment was conducted in triplicate. Four different inhibition models were applied by GraphPad Prism (version 7.03) software package to determine the best fit model and estimate the $I_{50}$ value. Equations of inhibition models are listed below.

Linear regression

$I \%=m \times N P s+n$

Modified non-competitive inhibition model

$I \%=100 \times\left(1-\frac{1}{1+\left(\frac{N P s}{a}\right)^{b}}\right)$

Non-linear dose-response inhibition models Inhibitor vs. normalized response

$A \%=\frac{100}{1+\frac{N P S}{a}}$

Inhibitor vs. normalized response -- Variable slope

$A \%=\frac{100}{1+\left(\frac{a}{N P S}\right)^{H i l l ~ s l o p e}}$

Non-linear second order polynomial (quadratic) model

$I \%=B 0+B 1 \times N P S+B 2 \times N P s^{2}$

Where $\mathrm{A} \%$ and $\mathrm{I} \%$ represent the activity and inhibition response of anammox process, respectively, NPs is the applied nanoparticle concentration, $a$ is the value causing $50 \%$ inhibition on nitrogen removal rate, $\mathrm{b}$ is a fitting parameter and $\mathrm{m}, \mathrm{B} 0, \mathrm{~B} 1, \mathrm{~B} 2$ are coefficients.

\section{Analytical procedures}

All analytical procedures including VSS, total suspended solids (TSS), $\mathrm{NH}_{4}{ }^{+}-\mathrm{N}$ and $\mathrm{NO}_{2}{ }^{-}-\mathrm{N}$ were determined according to Standard Methods (APHA, 2005). $\mathrm{pH}$ was measured by HQ40D digital portable multimeter ( $\mathrm{HACH}, \mathrm{USA})$.

\section{EPS analysis}

Protein (PN) and polysaccharides (PS) contents account for $75-89 \%$ of total EPS content (Tsuneda et al., 2003). Therefore, PN and PS concentrations in the samples were determined by modified Lowry method and Anthrone method, respectively. Prior to EPS quantification, modified heat extraction method, which was previously described by Morgan et al. (1990), was performed to extract EPS from mixed-liquor sludge samples. Subsequently, supernatant of the samples was filtered through $0.45 \mu \mathrm{M}$ and stored at $-20{ }^{\circ} \mathrm{C}$. Each measurement was performed with two independent samples and each sample was tested in duplicate. A UV2450 Spectrophotometer (Shimadzu, Japan) was used to conduct EPS measurements.

\section{SEM analysis}

Mixed-liquor sludge samples were firstly centrifuged at $3000 \mathrm{rpm}$ for $10 \mathrm{~min}$. Following the removal of supernatant, the pellet parts were washed three times for $3 \mathrm{~min}$ by $0.1 \mathrm{M}$ phosphate buffer to get 
rid of the unbounded materials. Thereafter, the pellets were fixed by fixation solution containing $2.5 \%(\mathrm{v} / \mathrm{v})$ glutaraldehyde in $0.1 \mathrm{M}$ phosphate buffer solution (PBS) at $4^{\circ} \mathrm{C}$ for $4 \mathrm{~h}$. In order to remove fixation solution, washing procedure was applied again. Finally, the pellets were dehydrated in 50\%, 70\%, 80\%, 90\% and $100 \%$ ethanol solutions, respectively for $15 \mathrm{~min}$ and transferred on grids. Following air drying, the samples were coated with platinum and the images were obtained by environmental scanning electron microscope (Philips XL30 ESEM-FEG /EDAX).

\section{Statistical analysis}

The results of the experiments were represented as the mean \pm standard deviation using Microsoft Excel. Paired t-test was also performed considering $P<0.05$ as statistically significant.

\section{Results and Discussion}

Acute exposure of $\mathrm{TiO}_{2}$ NPs on nitrogen removal performance of anammox process

SDBS, which is known as an anionic surfactant, was used as a dispersing agent in order to enhance the NPs stability and prevent their aggregation in the stock NPs solution. Previously published studies revealed no negative impacts of SDBS at low concentrations on biological processes including anaerobic treatment and anammox systems (Mu \& Chen, 2011; Mu et al., 2012; Qiao et al., 2016; Zhang et al., 2017). In the current study, it was observed that, $0.1 \mathrm{mM}$ SDBS has no statistically significant inhibitory impact on nitrogen removal efficiency of Anammox process $(\alpha=0.05, P=$ $0.25>0.05$ for $\mu 1=\mu 2$ ) (Figure 2).

In the scope of exposure tests, anammox bacteria were exposed to seven different $\mathrm{TiO}_{2} \mathrm{NPs}$ dosages from $1 \mathrm{mg} / \mathrm{L}$ to $300 \mathrm{mg} / \mathrm{L}$ for $24 \mathrm{~h}$ incubation in order to observe the acute effects of $\mathrm{TiO}_{2}$ NPs on nitrogen removal performance. Nitrogen concentrations in amber serum flasks were analyzed at every $3 \mathrm{~h}$.

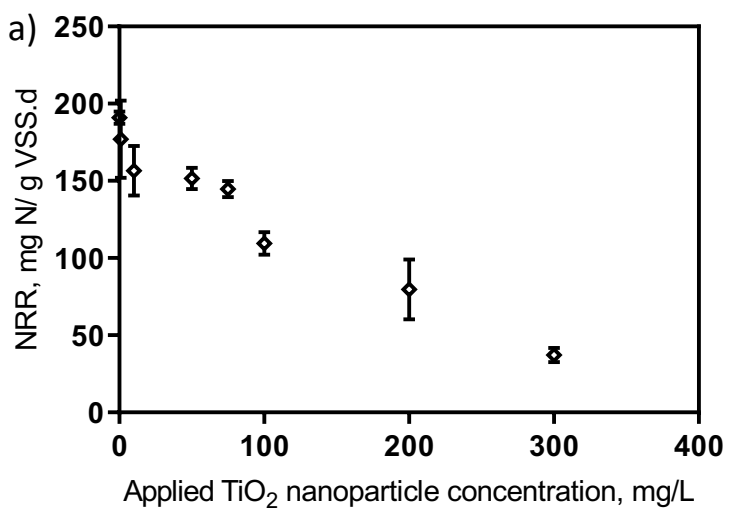

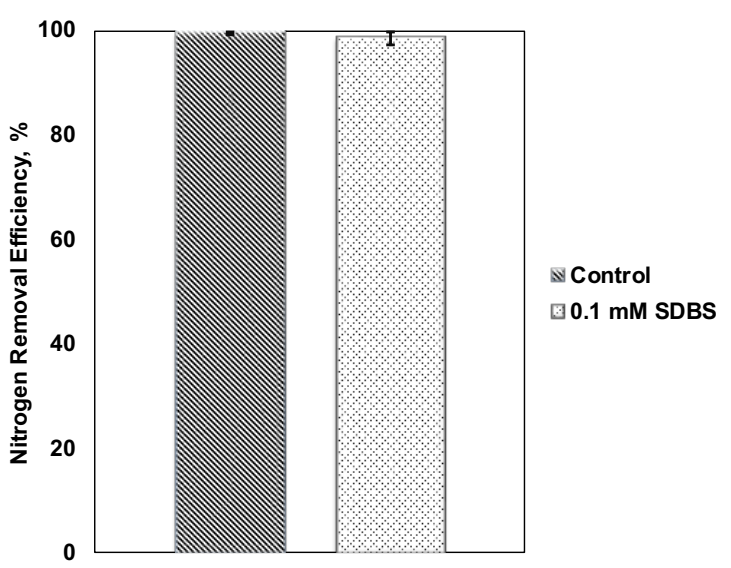

Figure 2. The effect of $0.1 \mathrm{mM}$ SDBS on nitrogen removal efficiency. Data indicate average, and error bars represent standard deviations of the results from three independent sampling.

Thereafter, nitrogen removal rates (NRR) of the enriched anammox culture were calculated for each dose using the maximum slope of nitrogen removal vs time curves. In the absence of $\mathrm{TiO}_{2} \mathrm{NPs}(0 \mathrm{mg} / \mathrm{L})$, NRR of anammox system was detected to be $190.94 \pm 12.93$ $\mathrm{mgN} / \mathrm{gVSS} . \mathrm{d}$. During the acute exposures of relatively small $\mathrm{TiO}_{2}$ NPs dosages ( $1 \mathrm{mg} / \mathrm{L}$ and $10 \mathrm{mg} / \mathrm{L}$ ), NRR was not significantly affected $(\alpha=0.05, P>0.05$ for $\mu 1=\mu 2)$ (Figure 3a). As the applied NPs dosage increased, the inhibition percentage also increased (Figure $3 \mathrm{~b}$ ). Along with the increase of NPs dose to $50 \mathrm{mg} / \mathrm{L}$, percentage inhibition reached to $20.62 \% \pm 1.70 \%$ and a statistically significant decrease was observed in NRR ( $\alpha=0.05, P=$ $0.02<0.05$ for $\mu 1=\mu 2$ ). When the applied dose was risen to $100 \mathrm{mg} / \mathrm{L}$ and/or higher loads, extremely significant deteriorations were observed in NRR $(\alpha=0.05, P<0.01$ for $\mu 1=\mu 2)$. In the presence of $300 \mathrm{mg} / \mathrm{L} \mathrm{TiO}{ }_{2} \mathrm{NPs}$ dosage, NRR was dramatically decreased to $37.09 \pm 0.24$ $\mathrm{mgN} / \mathrm{gVSS} . \mathrm{d}$ and a severe inhibition $(80.57 \pm 1.17 \%)$ was observed (Figure 3a \& 3b).

In order to examine the response of anammox bacteria to NPs stress, several inhibition models namely,

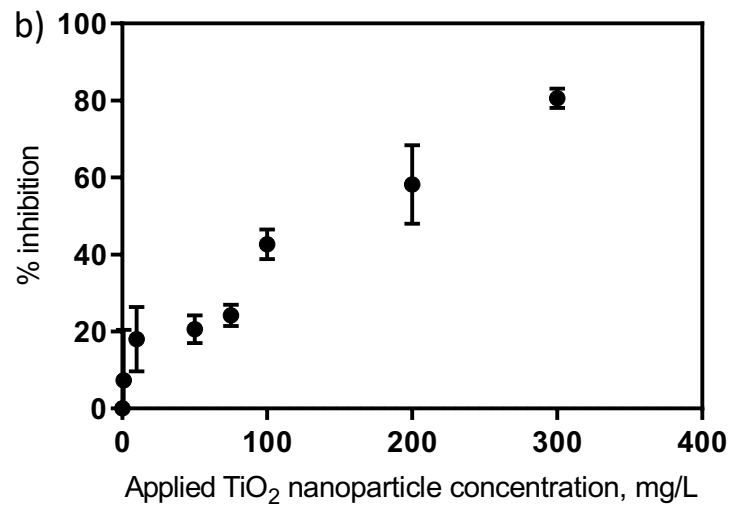

Figure 3. Acute effects of $\mathrm{TiO}_{2} \mathrm{NPs}$ on anammox activity. a) nitrogen removal rate in the presence of $\mathrm{TiO}_{2} \mathrm{NPs}_{\mathrm{b}}$ ) percent inhibition (\%) response of the applied $\mathrm{TiO}_{2} \mathrm{NPs}$ dosage. Data indicate average, and error bars represent standard deviations of samples measured in triplicate. 
linear regression, modified non-competitive inhibition model, non-linear dose-response inhibition models, and non-linear second order polynomial (quadratic) model were tested (Figure 4). In all models, the $\mathrm{IC}_{50}$ of $\mathrm{TiO}_{2} \mathrm{NPs}$ on anammox activity was calculated. Compliance of the experimental data and determining the reliable curve fitting were evaluated by the $R^{2}$ value. The best fit curve was obtained with the non-linear second order polynomial (quadratic) model. In this model, the $\mathrm{IC}_{50}$ was determined to be $154 \mathrm{mg} / \mathrm{L}\left(R^{2}=0.964\right)$.

In the literature, there is only one study that highlights the short-term effects of $\mathrm{TiO}_{2} \mathrm{NPs}$ on Anammox process (X. J. Zhang et al., 2018a) with an exposure time of $8 \mathrm{~h}$. In that study, it is reported that, 1 $\mathrm{mg} / \mathrm{L}$ NPs concentration enhanced the anammox activity while $5-20 \mathrm{mg} / \mathrm{L}$ dosages inhibited the anammox activity. It was also emphasized that $50 \mathrm{mg} / \mathrm{L} \mathrm{TiO} 2 \mathrm{NPs}$ dose showed lower suppression. On the contrary, this study demonstrated that acute exposure of $\mathrm{TiO}_{2} \mathrm{NPs}$ caused inhibition on Anammox process. The inhibition severity also rose as the applied dose was increased. The difference in the incubation period of acute exposure tests may be the most probable reason for different outcomes. In a recently published study, it was stated

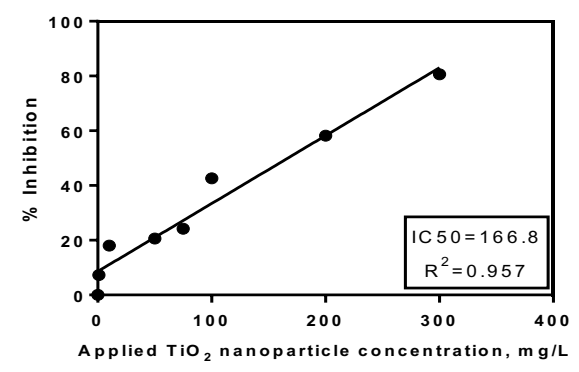

(a)

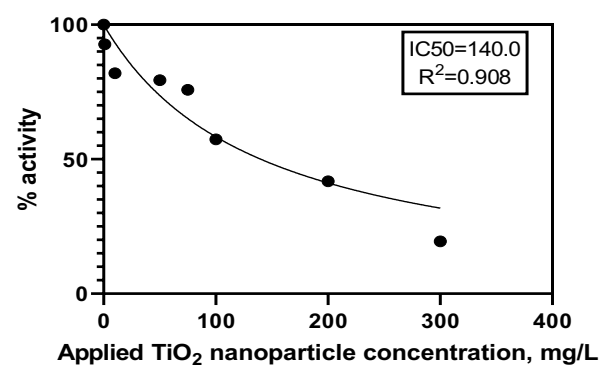

(c) that, less than $12 \mathrm{~h}$ exposure period is not adequate to examine the anammox response against the inhibitory factors (Song et al., 2018). Besides these, not only the experimental setups but also the use of anammox granules/flocs and/or dominant anammox species in the enriched anammox culture may lead to the variations in the findings.

\section{Attitudes of NPs in Anammox reactor}

At the end of each acute exposure test, surface morphology of anammox bacteria was observed by SEM images. $\mathrm{TiO}_{2}$ NPs mainly exist in solid phases because of their highly insoluble characteristic (Zheng et al., 2011). They tend to adsorb on biological surfaces or form aggregates with each other rather than the ion form (Cervantes-Aviles et al., 2017; Kokalj et al., 2018). As shown in Figure 5, $\mathrm{TiO}_{2} \mathrm{NPs}$ made clusters and attached to the surface of the bacteria. Moreover, when the applied dosage increased, amount of attached NPs also increased. Therefore, the substrate transfer rate between the environment and bacteria was possibly eliminated and NRR of Anammox process decreased. On the other hand, it has already been known that the larger the particle size is, the lower the toxicity. Hence,

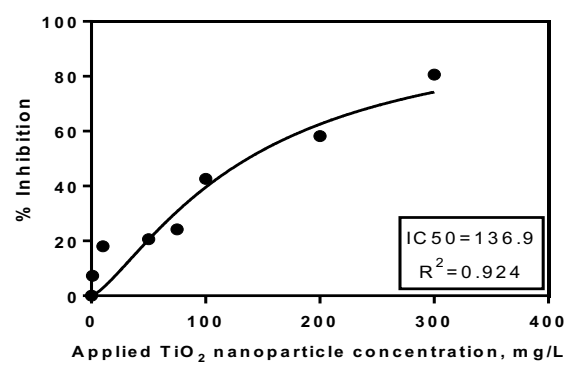

(b)

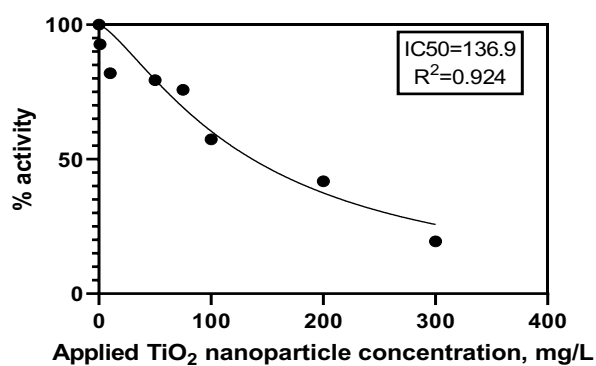

(d)

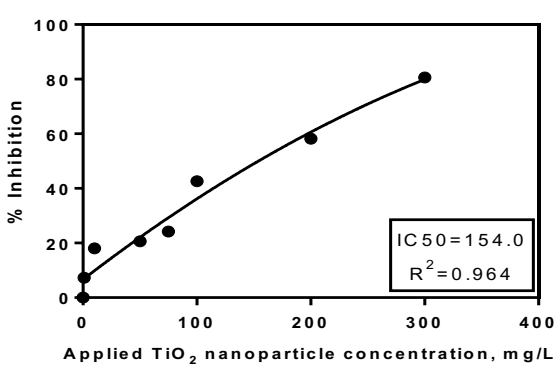

(e)

Figure 4. Inhibition response of the applied $\mathrm{TiO}_{2} \mathrm{NPs}$ dosage with different inhibition models. a) linear regression; b) modified noncompetitive model; c) Inhibitor vs. normalized response; d) Inhibitor vs. normalized response - Variable slope; e) non-linear second order polynomial (quadratic) model. 
due to the clustering of $\mathrm{TiO}_{2} \mathrm{NPs}$, particle size may increase, which may lead to lower toxicity. As a different perspective, the EPS produced by the bacteria may trap the NPs and protect the bacteria assisting the aggregation of NPs. Even though, it was formerly speculated that $\mathrm{TiO}_{2} \mathrm{NPs}$ cannot be accumulated in high quantities on not only bacterial cell wall but also EPS due to electrostatic repulsions (Huangfu et al., 2019), SEM analysis exhibited the aggregation of $\mathrm{TiO}_{2} \mathrm{NPs}$ on anammox bacteria. A previous study also demonstrated the deposition of significant amount of metal oxide NPs including $\mathrm{TiO}_{2}$ on the outer layer of anammox granules (Z. Z. Zhang et al., 2018b).

\section{EPS response of Anammox bacteria}

EPS, an organic matrix containing proteins, carbohydrates, DNA and lipids (Tang et al., 2018), is secreted by various microorganisms in anammox granules. Not only it protects microorganisms from adverse conditions as a first barrier against to environmental stress such as heavy metals and NPs, but also it plays an important role in accelerating the granulation process, improving stability of the matrix structure and granules (Yang et al., 2013; Zhang et al., 2015, 2017). Therefore, it is necessary to track EPS released by enriched anammox culture after acute exposure tests in order to understand the role of EPS in the resistance of anammox system against $\mathrm{TiO}_{2} \mathrm{NPs}$.

Type of biological systems and the properties of NPs specify the potential effects of metal NPs (Xu et al., 2019). Thus, there have been various outcomes about the EPS responses of microorganisms. Decrement in PN content of anaerobic granular sludge against elevating ZnO NP concentration from 10 to $200 \mathrm{mg} / \mathrm{g}$ TSS was reported by $\mathrm{Mu}$ et al. (2012) while some studies were stated increment in EPS secretion in the existence of metal NPs including $\mathrm{CuO}, \mathrm{CeO}_{2}$ (Hou et al., 2015; Ma et al., 2013; You et al., 2017). Furthermore, some studies revealed that, $\mathrm{NPs}(\mathrm{ZnO}, \mathrm{NiO})$ at lower concentrations firstly could rise up the EPS amount while higher loads of the same NPs decrease the EPS amount (He et al., 2017; Xu et al., 2019).

In the current study, the total EPS content gradually decreased with escalating burden of $\mathrm{TiO}_{2} \mathrm{NPS}$
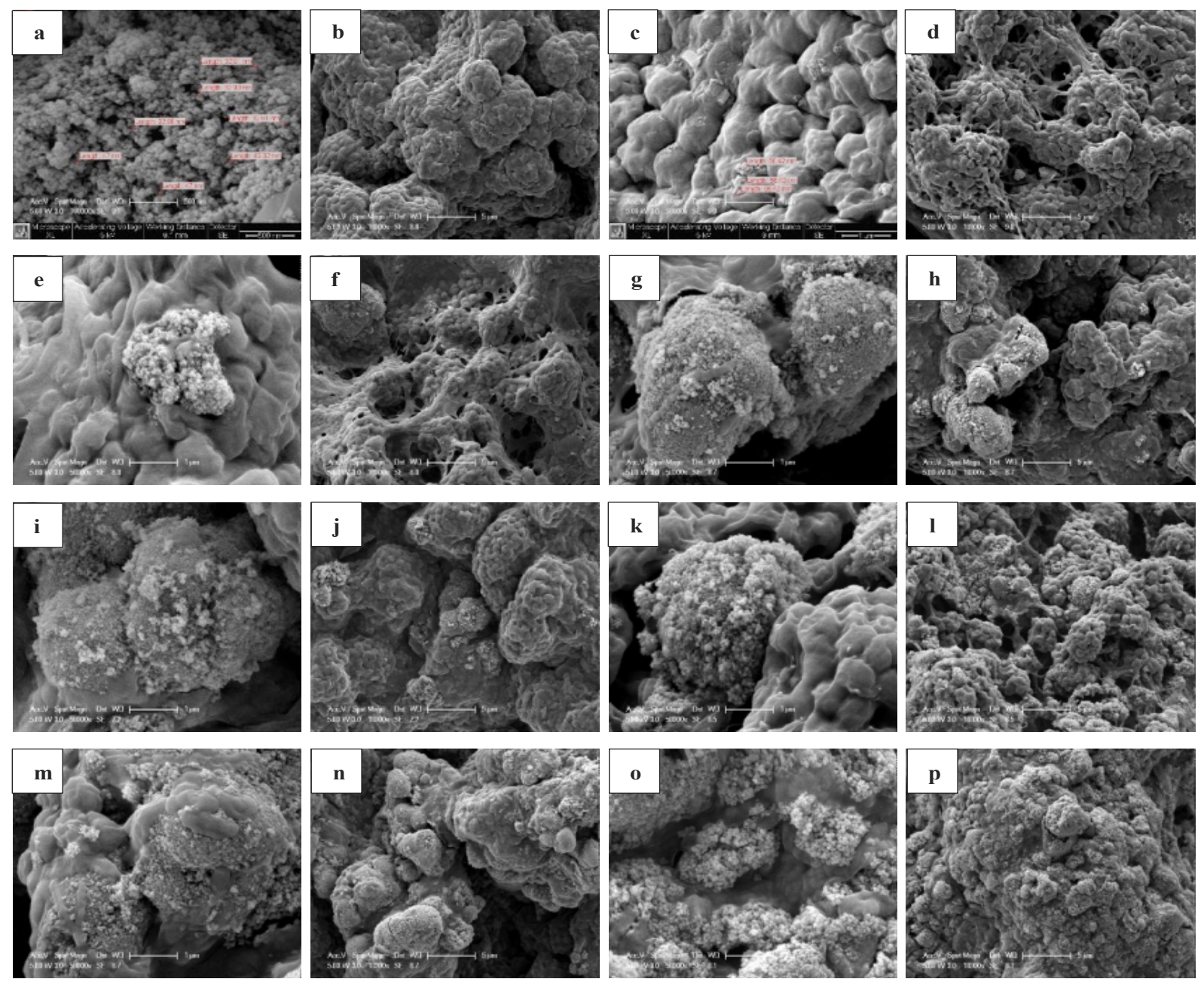

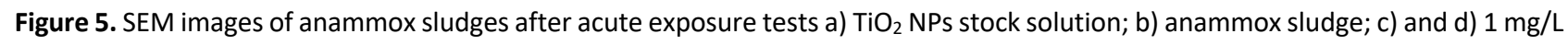
$\mathrm{TiO}_{2} \mathrm{NPs}$ exposure; e) and f) $10 \mathrm{mg} / \mathrm{L} \mathrm{TiO}_{2} \mathrm{NPs}$ exposure; g) and h) $50 \mathrm{mg} / \mathrm{L} \mathrm{TiO}{ }_{2} \mathrm{NPs}$ exposure; i) and j) $75 \mathrm{mg} / \mathrm{L} \mathrm{TiO}{ }_{2} \mathrm{NPs}$ exposure; $\mathrm{k}$ ) and I) $100 \mathrm{mg} / \mathrm{L} \mathrm{TiO}_{2} \mathrm{NPs}$ exposure; m) and n) $200 \mathrm{mg} / \mathrm{L} \mathrm{TiO}_{2} \mathrm{NPs}$ exposure; o) and p) $300 \mathrm{mg} / \mathrm{L} \mathrm{TiO} \mathrm{NPs}_{2}$ exposure. 
dosage (Figure 6). Numerically, $49.73 \%$ and $92.19 \%$ decrements in total EPS content was determined after the acute exposures of $50 \mathrm{mg} / \mathrm{L}$ and $300 \mathrm{mg} / \mathrm{L} \mathrm{TiO} 2 \mathrm{NPs}$ dosages, respectively. During all the exposure experiments, PN production was greater than PS production. Therefore, it could be interpreted that, sensitivity of PN to $\mathrm{TiO}_{2}$ NPs was more than that of PS. Similar findings also revealed by other studies focused on other NPs (Xu et al., 2019; Xu et al., 2018).

In a recent study, Z. Z. Zhang et al. (2018b) investigated the long-term effects of $\mathrm{TiO}_{2} \mathrm{NPs}$ on Anammox process at three different NPs dosages (1 $\mathrm{mg} / \mathrm{L}, 50 \mathrm{mg} / \mathrm{L}, 150 \mathrm{mg} / \mathrm{L}$ ) for a month each and reported the enhancement of EPS production during the exposure period and highlighted the EPS secretion as adaptation strategy. In this study, however, the anammox biomass was exposed to shock loads of NPs within a short time. Hence, anammox bacteria may not be able to adapt to the changing environment and could not produce enough EPS to protect the cellular structure against the inhibitory compound. This phenomenon may also be explained by the longer lag phase of EPS secretion in anammox population compared to the heterotrophs because of their relatively slow growth rates (Song et al., 2018). Besides, the differences in exposure periods of the same NPs may change the EPS responses. Zhao et al. (2019) pointed out $24 \mathrm{~h}$ shortterm exposure of ZnO NPs (5, 50, $150 \mathrm{mg} / \mathrm{L}$ ) caused gradually decrement in EPS release by anammox granules. However, Sari et al. (2020) emphasized that, long-term exposure of ZnO NPs increased the EPS secretion in anammox reactor up to $40 \mathrm{mg} / \mathrm{L} \mathrm{NPs}$ dosage. Consequently, in the current study, the EPS production gradually decreased inversely proportional to the increase in inhibition percentage.

\section{Conclusion}

Acute response of $\mathrm{TiO}_{2} \mathrm{NPs}$ on Anammox process at seven different dosages $(1,10,50,75,100,200,300$ $\mathrm{mg} / \mathrm{L}$ ) was examined for $24 \mathrm{~h}$ incubation period. When the concentration was risen to $50 \mathrm{mg} / \mathrm{L}$, a significant deterioration on NRR was obtained. Inhibition percentage on anammox activity was gradually increased by escalating the burden of applied $\mathrm{TiO}_{2}$ NPs dosage. At $300 \mathrm{mg} / \mathrm{L}$ exposure dose, NRR was dramatically decreased from $190.94 \pm 12.93$ to $37.09 \pm$ $0.24 \mathrm{mgN} / \mathrm{gVSS} . \mathrm{d}$ and a severe inhibition $(80.57 \% \pm$ $1.17 \%)$ was observed. Several inhibition models were tested in order to estimate the $I_{50}$ value. Non-linear second order polynomial (quadratic) model was the best fit model with $R^{2}=0.964$. The $I C_{50}$ value was determined to be $154 \mathrm{mg} / \mathrm{L}$ with this model. At the end of the acute exposure tests, surface morphology of anammox bacteria was also observed by SEM images. The results revealed that, $\mathrm{TiO}_{2} \mathrm{NPs}$ tended to form cluster and attached to the surface of the bacteria. Moreover, as the applied NPs dosage increased, amount of attached NPs also increased. Finally, EPS secretion by enriched anammox culture was tracked in order to analyze the response of the anammox system. The total EPS content gradually decreased by increasing $\mathrm{TiO}_{2}$ NPs dosage which is inversely proportional to the increase in inhibition percentage of anammox activity.

\section{Acknowledgements}

This study was funded by the Scientific and Technological Research Council of Turkey (TUBITAKProject No: 117Y214) and Marmara University Scientific Research Committee (BAPKO- Project No: FEN-C-YLP-

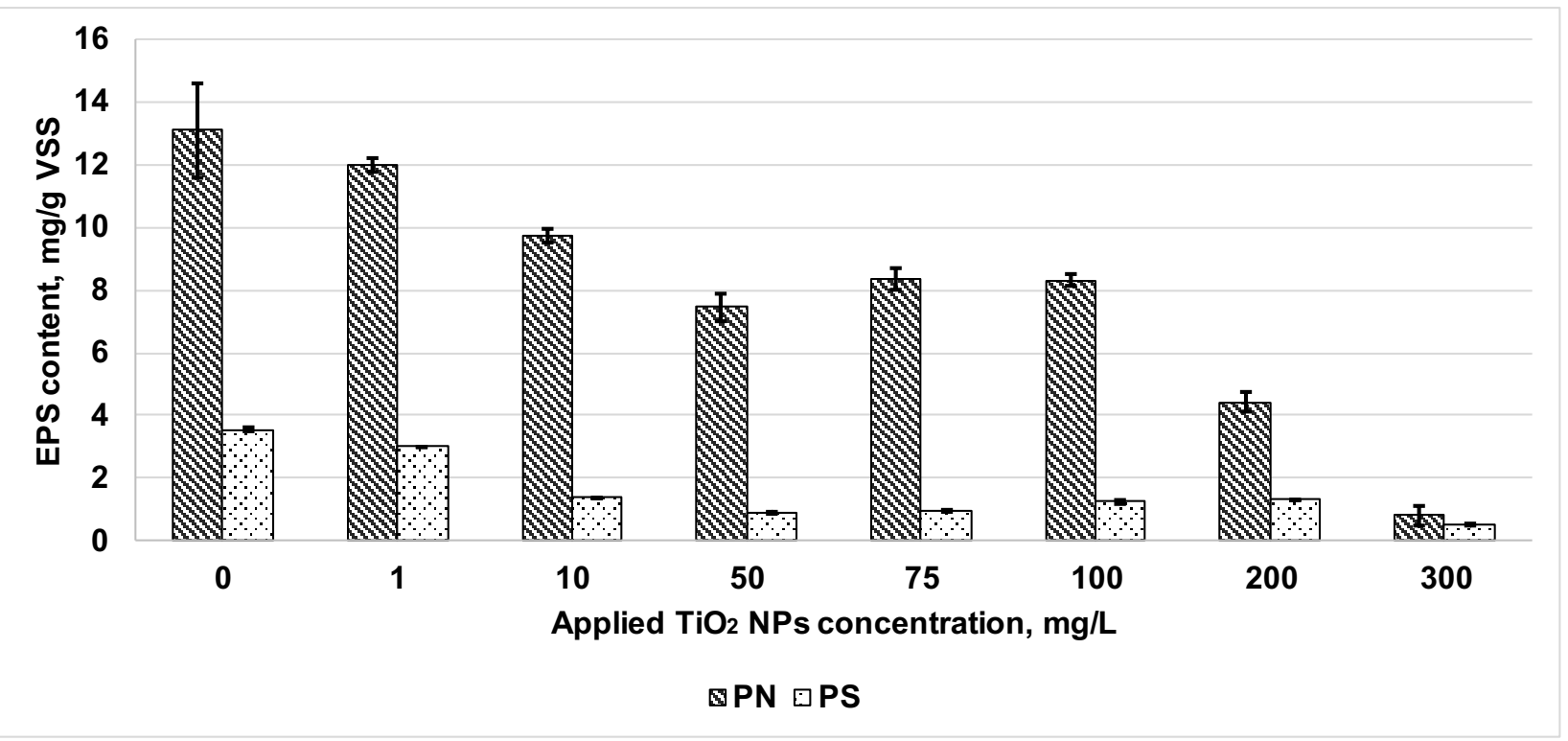

Figure 6. EPS secretion by enriched anammox culture exposed to $\mathrm{TiO}_{2} \mathrm{NPs}$. Data indicate average, and error bars represent standard deviation of the results from two independent sampling, each tested in duplicate. 
090217-0054). The authors express their gratitude to Prof. Bulent Mertoglu for sharing his laboratory infrastructure and Prof. Kozet Yapsakli for her helps in model studies.

\section{Credit}

Portions of this paper were presented at the ICETI Conference held in Sarajevo Bosnia and Herzegovina, March 22-26, 2017.

\section{References}

Bhushan, B. (2017). Introduction to Nanotechnology In B. Bhushan (Ed.), Springer Handbook of Nanotechnology (4 ed., pp. 1-18). Berlin, Germany: Springer.

Cao, Y. S., van Loosdrecht, M. C. M., \& Daigger, G. T. (2017). Mainstream partial nitritation-anammox in municipal wastewater treatment: status, bottlenecks, and further studies. Applied Microbiology and Biotechnology, 101(4), 1365-1383.

Cervantes-Aviles, P., Pinas, N. C., Ida, J., \& Cuevas-Rodriguez, G. (2017). Influence of wastewater type on the impact generated by $\mathrm{TiO}_{2}$ nanoparticles on the oxygen uptake rate in activated sludge process. Journal of Environmental Management, 190, 35-44.

Chen, R., \& Chen, C. (2017). Environment, Health and Safety Issues in Nanotechnology. In B. Bhushan (Ed.), Springer Handbook of Nanotechnology (pp. 1559-1586). Berlin, Germany: Springer.

Gupta, R., \& Xie, H. (2018). Nanoparticles in Daily Life: Applications, Toxicity and Regulations. Journal of Environmental Pathology Toxicology and Oncology, 37(3), 209-230.

He, Q. L., Gao, S. X., Zhang, S. L., Zhang, W., \& Wang, H. Y. (2017). Chronic responses of aerobic granules to zinc oxide nanoparticles in a sequencing batch reactor performing simultaneous nitrification, denitrification and phosphorus removal. Bioresource Technology, 238, 95-101.

Heil, J., Vereecken, H., \& Bruggemann, N. (2016). A review of chemical reactions of nitrification intermediates and their role in nitrogen cycling and nitrogen trace gas formation in soil. European Journal of Soil Science, 67(1), 23-39.

Hou, J., Miao, L. Z., Wang, C., Wang, P. F., Ao, Y. H., \& Lv, B. W. (2015). Effect of $\mathrm{CuO}$ nanoparticles on the production and composition of extracellular polymeric substances and physicochemical stability of activated sludge flocs. Bioresource Technology, 176, 65-70.

Huangfu, X. L., Xu, Y. H., Liu, C. H., He, Q., Ma, J., Ma, C. X., \& Huang, R. X. (2019). A review on the interactions between engineered nanoparticles with extracellular and intracellular polymeric substances from wastewater treatment aggregates. Chemosphere, 219, 766-783.

Jin, R. C., Yang, G. F., Yu, J. J., \& Zheng, P. (2012). The inhibition of the Anammox process: A review. Chemical Engineering Journal, 197, 67-79.

Kaphle, A., Nagaraju, N., \& Daima, H. K. (2018). Contemporary Developments in Nanobiotechnology: Applications, Toxicity, Sustainability, and Future Perspective. In A. Dhawan, S. Singh, A. Kumar, \& R. Shanker (Eds.), Nanobiotechnology: Human Health and the Environment (pp. 1-34). Boca Raton, Florida: CRC Press.
Keller, A. A., \& Lazareva, A. (2014). Predicted Releases of Engineered Nanomaterials: From Global to Regional to Local. Environmental Science \& Technology Letters, 1(1), 65-70.

Kokalj, A. J., Drobne, D., \& Novak, S. (2018). Nanotoxicology: Toxicity Evaluation, Risk Assessment and Management. Boca Raton, Florida: CRC Press.

Li, H., Chi, Z. F., \& Yan, B. X. (2018). Insight into the impact of $\mathrm{Fe} 3 \mathrm{O} 4$ nanoparticles on anammox process of subsurface-flow constructed wetlands under long-term exposure. Environmental Science and Pollution Research, 25(29), 29584-29592.

Liu, G. Q., Wang, D. M., Wang, J. M., \& Mendoza, C. (2011). Effect of $\mathrm{ZnO}$ particles on activated sludge: Role of particle dissolution. Science of the Total Environment, 409(14), 2852-2857.

Liu, W. Z., Weng, C. Z., Zheng, J. Y., Peng, X. Q., Zhang, J., \& Lin, Z. (2019). Emerging investigator series: treatment and recycling of heavy metals from nanosludge. Environmental Science-Nano, 6(6), 1657-1673.

Lombi, E., Donner, E., Tavakkoli, E., Turney, T. W., Naidu, R., Miller, B. W., \& Scheckel, K. G. (2012). Fate of Zinc Oxide Nanoparticles during Anaerobic Digestion of Wastewater and Post-Treatment Processing of Sewage Sludge. Environmental Science \& Technology, 46(16), 9089-9096.

Ma, J. Y., Quan, X. C., Si, X. R., \& Wu, Y. C. (2013). Responses of anaerobic granule and flocculent sludge to ceria nanoparticles and toxic mechanisms. Bioresource Technology, 149, 346-352.

Mohamed, H. R. H. (2018). Genotoxicity and Carcinogenicity of Daily Used Nanoparticles: In Vivo Studies. In V. Kumar, N. Dasgupta, \& S. Ranjan (Eds.), Nanotoxicology: Toxicity Evaluation, Risk Assessment and Management (pp. 193218). Boca Raton, Florida: CRC Press.

Morgan, J. W., Forster, C. F., \& Evison, L. (1990). A Comparative-Study of the Nature of Biopolymers Extracted from Anaerobic and Activated Sludges. Water Research, 24(6), 743-750.

$\mathrm{Mu}$, H., \& Chen, Y. G. (2011). Long-term effect of ZnO nanoparticles on waste activated sludge anaerobic digestion. Water Research, 45(17), 5612-5620.

Mu, H., Zheng, X., Chen, Y. G., Chen, H., \& Liu, K. (2012). Response of Anaerobic Granular Sludge to a Shock Load of Zinc Oxide Nanoparticles during Biological Wastewater Treatment. Environmental Science \& Technology, 46(11), 5997-6003.

Mulder, A., Vandegraaf, A. A., Robertson, L. A., \& Kuenen, J. G. (1995). Anaerobic Ammonium Oxidation Discovered in a Denitrifying Fluidized-Bed Reactor. Fems Microbiology Ecology, 16(3), 177-183.

Musee, N., Thwala, M., \& Nota, N. (2011). The antibacterial effects of engineered nanomaterials: implications for wastewater treatment plants. Journal of Environmental Monitoring, 13(5), 1164-1183.

Peeters, S. H., \& van Niftrik, L. (2019). Trending topics and open questions in anaerobic ammonium oxidation. Current Opinion in Chemical Biology, 49, 45-52.

Qiao, S., Zheng, N., Tian, T., Yu, C., \& Zhou, J. T. (2016). Effects of short-term exposure to linear anionic surfactants (SDBS, SLS and SDS) on anammox biomass activity. Rsc Advances, 6(58), 53004-53011.

Robertson, G. P., \& Groffman, P. M. (2015). Nitrogen Transformations. In E. A. Paul (Ed.), Soil microbiology, 
ecology and biochemistry (4 ed., pp. 421-446). Burlington, Massachusetts, USA: Academic Press.

Sari, T., Can, S., \& Akgul, D. (2020). Assessment of Anammox process against acute and long-term exposure of $\mathrm{ZnO}$ nanoparticles. Science of the Total Environment, 727.

Senapati, V. A., \& Kumar, V. (2018). Nanoparticles and the Aquatic Environment: Application, Impact and Fate. In A. Dhawan, S. Singh, S. Kumar, \& R. Shanker (Eds.), Nanobiotechnology: Human Health and the Environment (pp. 299-323). Boca Raton, Florida: CRC Press.

Song, Y. X., Chai, L. Y., Tang, C. J., Xiao, R. Y., Li, B. R., Wu, D., \& Min, X. B. (2018). Influence of $\mathrm{ZnO}$ nanoparticles on anammox granules: The inhibition kinetics and mechanism analysis by batch assays. Biochemical Engineering Journal, 133, 122-129.

Stein, L. Y., \& Klotz, M. G. (2016). The nitrogen cycle. Current Biology, 26(3), R94-R98.

Tang, J., Wu, Y. H., Esquivel-Elizondo, S., Sorensen, S. J., \& Rittmann, B. E. (2018). How Microbial Aggregates Protect against Nanoparticle Toxicity. Trends in Biotechnology, 36(11), 1171-1182.

Tsuneda, S., Aikawa, H., Hayashi, H., Yuasa, A., \& Hirata, A. (2003). Extracellular polymeric substances responsible for bacterial adhesion onto solid surface. Fems Microbiology Letters, 223(2), 287-292.

Wu, Q., Huang, K. L., Sun, H. H., Ren, H. Q., Zhang, X. X., \& Ye, L. (2018). Comparison of the impacts of zinc ions and zinc nanoparticles on nitrifying microbial community. Journal of Hazardous Materials, 343, 166-175.

Xu, J. J., Cheng, Y. F., Xu, L. Z. J., Liu, Y. Y., Zhu, B. Q., Fan, N. S., Huang, B. C., \& Jin, R. C. (2019). The revolution of performance, sludge characteristics and microbial community of anammox biogranules under long-term NiO NPs exposure. Science of the Total Environment, 649, 440-447.

Xu, J. J., Zhu, X. L., Zhang, Q. Q., Cheng, Y. F., Xu, L. Z. J., Zhu, Y. H., Ji, Z. Q., \& Jin, R. C. (2018). Roles of $\mathrm{MnO}_{2}$ on performance, sludge characteristics and microbial community in anammox system. Science of the Total Environment, 633, 848-856.

Yang, G. F., Ni, W. M., Wu, K., Wang, H., Yang, B. E., Jia, X. Y., \& Jin, R. C. (2013). The effect of Cu(II) stress on the activity, performance and recovery on the Anaerobic Ammonium-Oxidizing (Anammox) process. Chemical Engineering Journal, 226, 39-45.

Yapsakli, K., Aktan, C. K., \& Mertoglu, B. (2017). Anammoxzeolite system acting as buffer to achieve stable effluent nitrogen values. Biodegradation, 28(1), 69-79.

You, G. X., Wang, P. F., Hou, J., Wang, C., Xu, Y., Miao, L. Z., Lv, B., Yang, Y., Liu, Z., \& Zhang, F. (2017). Insights into the short-term effects of $\mathrm{CeO}_{2}$ nanoparticles on sludge dewatering and related mechanism. Water Research, 118, 93-103.

Zhang, L. L., Zhang, Z. X., He, X., Zheng, L., Cheng, S. K., \& Li, Z. F. (2019). Diminished inhibitory impact of $\mathrm{ZnO}$ nanoparticles on anaerobic fermentation by the presence of $\mathrm{TiO}_{2}$ nanoparticles: Phenomenon and mechanism. Science of the Total Environment, 647, 313322.

Zhang, X. J., Zhou, Y., Ma, Y. P., Zhang, H., Li, Y. Z., Yang, J. C., Xie, X. Y., \& Pang, Q. (2018a). Short-Term Effects of CuO, $\mathrm{ZnO}$, and $\mathrm{TiO}_{2}$ Nanoparticles on Anammox. Environmental Engineering Science, 35(12), 1294-1301.

Zhang, X. J., Zhou, Y., Xu, T. F., Zheng, K. W., Zhang, R. R., Peng, Z. X., \& Zhang, H. Z. (2018b). Toxic effects of CuO, ZnO and $\mathrm{TiO}_{2}$ nanoparticles in environmental concentration on the nitrogen removal, microbial activity and community of Anammox process. Chemical Engineering Journal, 332, 42-48.

Zhang, Z. Z., Deng, R., Cheng, Y. F., Zhou, Y. H., Buayi, X., Zhang, X., Wang, H. Z., \& Jin, R. C. (2015). Behavior and fate of copper ions in an anammox granular sludge reactor and strategies for remediation. Journal of Hazardous Materials, 300, 838-846.

Zhang, Z. Z., Zhang, Q. Q., Xu, J. J., Deng, R., Ji, Z. Q., Wu, Y. H., \& Jin, R. C. (2016). Evaluation of the inhibitory effects of heavy metals on anammox activity: A batch test study. Bioresource Technology, 200, 208-216.

Zhang, Z. Z., Xu, J. J., Shi, Z. J., Cheng, Y. F., Ji, Z. Q., Deng, R., \& Jin, R. C. (2017). Short-term impacts of Cu, CuO, ZnO and Ag nanoparticles (NPs) on anammox sludge: CuNPs make a difference. Bioresource Technology, 235, 281-291.

Zhang, Z. Z., Cheng, Y. F., Bai, Y. H., Xu, L. Z. J., Xu, J. J., Shi, Z. J., Zhang, Q. Q., \& Jin, R. C. (2018a). Enhanced effects of maghemite nanoparticles on the flocculent sludge wasted from a high-rate anammox reactor: Performance, microbial community and sludge characteristics. Bioresource Technology, 250, 265-272.

Zhang, Z. Z., Cheng, Y. F., Xu, L. Z. J., Bai, Y. H., Xu, J. J., Shi, Z. J., Shen, Y. Y., \& Jin, R. C. (2018b). Evaluating the effects of metal oxide nanoparticles $\left(\mathrm{TiO}_{2}, \mathrm{Al}_{2} \mathrm{O}_{3}, \mathrm{SiO}_{2}\right.$ and $\left.\mathrm{CeO}_{2}\right)$ on anammox process: Performance, microflora and sludge properties. Bioresource Technology, 266, 11-18.

Zhao, J., Zhang, B. W., \& Zuo, J. E. (2019). Response of anammox granules to $\mathrm{ZnO}$ nanoparticles at ambient temperature. Environmental Technology \& Innovation, $13,146-152$.

Zheng, X., Chen, Y. G., \& Wu, R. (2011). Long-Term Effects of Titanium Dioxide Nanoparticles on Nitrogen and Phosphorus Removal from Wastewater and Bacterial Community Shift in Activated Sludge. Environmental Science \& Technology, 45(17), 7284-7290. 